\title{
BAURAN PEMASARAN DAN KEPUASAN KONSUMEN AGEN LAKU PANDAI PT. BANK XYZ
}

\author{
MARKETING MIX AND SATISFACTION OF THE CUSTOMERS OF \\ LAKU PANDAI AGENCU OF PT. BANK XYZ
}

\author{
Rano Hendranata $^{* 1}$, M. Syamsul Ma'arif ${ }^{\text {**) }}$, dan Kirbrandoko ${ }^{* * *}$ \\ *) PT. Bank BRI \\ Jl. Jend. Sudirman Jakarta Pusat Indonesia \\ **) Sekolah Bisnis, Institut Pertanian Bogor \\ Gedung SB-IPB Jl. Raya Pajajaran, Bogor 16151 \\ $\left.{ }^{* * *}\right)$ Pascasarjana Universitas Ibn Khaldun \\ Jl. K.H. Sholeh Iskandar Km. 2 Bogor 16162
}

\begin{abstract}
Marketing management is one element that is used by XYZ Bank to introduce its products widely known by the public. Laku Pandai is one of the Bank XYZ network developments with the concept of agency that promotes the development of the economy at the level of Laku Pandai Agent and increases customer satisfaction. The research used the Important Performance Analysis (IPA) aiming to determine the interest and performance of the customers of the Laku Pandai Agent. The results showed that the tools/technology variables used, product knowledge and good manner of the agents, and quick and easy transactions had high interests and satisfaction for the consumers. The study used the Structural Equation Modeling (SEM) to analyze the effects of marketing mix on customer satisfaction and loyalty. The results of the research showed that the empathy variable was the most determinant variable on satisfaction for the consumers of the agency when compared to the other variables of Tangible, Reliability, Assurance and Responsibility. Overall, the respondents were satisfied with the quality of services provided by Laku Pandai Agency.
\end{abstract}

Keywords: agen laku pandai, marketing mix, IPA, SEM

\begin{abstract}
Abstrak: Manajemen pemasaran merupakan salah satu unsur yang dipergunakan oleh perusahaan untuk memperkenalkan produk-produk Bank XYZ sehingga dikenal oleh masyarakat. Laku Pandai merupakan salah satu pengembangan jaringan Bank XYZ dengan konsep keagenan yang mengutamakan pengembangan tingkat perekonomian Agen Laku Pandai dan peningkatan kepuasan pelanggan. Penelitian menggunakan Important Performance Analysis (IPA) bertujuan mengetahui kepentingan dan kinerja dari nasabah Agen Laku Pandai. Hasil menunjukkan bahwa variabel alat/teknologi yang digunakan, pengetahuan produk Agen Laku Pandai, sopan santun Agen Laku Pandai serta transaksi yang cepat, mudah, selalu berhasil memiliki kepentingan tinggi dan memberikan kepuasan bagi konsumen. Penelitian dengan menggunakan Structural Equation Modelling (SEM) dimaksudkan untuk menganalisis pengaruh bauran pemasaran terhadap kepuasan dan loyalitas konsumen. Hasil penelitian menunjukkan bahwa variabel emphaty merupakan variabel yang paling menentukan kepuasan konsumen Agen Laku Pandai bila dibandingkan dari variabel lainnya, yaitu Tangible, Realibility, Assurane dan Responsibility. Secara keseluruhan responden merasa puas dengan kualitas layanan yang diberikan oleh Agen Laku Pandai.
\end{abstract}

Kata kunci: agen laku pandai, bauran pemasaran, IPA, SEM

\footnotetext{
${ }^{1}$ Alamat Korespondensi:

Email: rano.ariyanti@gmail.com
} 


\section{PENDAHULUAN}

Dalam rangka mewujudkan "reach the unreachable" sehingga dapat menjangkau unbanked people di seluruh wilayah kepulauan Indonesia maka Otoritas Jasa Keuangan (OJK) melakukan sosialisasi tentang program literasi keuangan bagi masyakat Indonesia. Saat ini masih banyak masyarakat Indonesia yang belum mengenal perbankan, hal inilah yang menjadi salah satu faktor para perbankan lokal dan asing sangat tertarik untuk berinvestasi dari sektor jasa keuangan di Indonesia karena peluang masih sangat besar untuk dikembangkan.

Pemerintah melalui OJK terus melakukan pendekatan terhadap masyarakat dengan melakukan pembukaan unit kerja perbankan di seluruh Indonesia dari Sabang sampai Merauke, sekaligus melakukan kontrol yang ketat dari guna memberikan jaminan kepercayaan bagi masyarakat atas kinerja perbankan Indonesia. Saat ini jumlah Bank di Indonesia sebanyak 118 bank umum dengan jumlah kantor bank mencapai 32.939 kantor Bank Umum menurut data Bank Indonesia Oktober 2015. Hal ini menjadikan tantangan bagi Bank XYZ untuk memperluas jaringannya dan membuka kesempatan melakukan inovasi dalam pembukaan kantor yang lebih dekat, produk yang lebih lengkap dan memiliki jaringan yang bagus.

Melihat peluang dan tantangan tersebut, maka Bank XYZ sejak awal tahun 2015 mengeluarkan produk Laku Pandai, Laku Pandai sendiri adalah layanan perluasan Bank XYZ yang bekerja sama dengan nasabahnya yaitu para Agen dengan menawarkan layanan dan produk mini ATM, TBank dan Tabunganku (Laku Pandai) yang dapat dipergunakan bagi masyarakat baik yang merupakan nasabah Bank XYZ maupun non-nasabah Bank XYZ. Sebagai Bank yang memiliki jaringan terluas dan terbesar di Indonesia, Laku Pandai merupakan jawaban lainnya dari Bank XYZ bagi masyarakat sehingga masyarakat akan lebih mudah dalam mengakses layanan perbankan.

Dalam rangka memenuhi literasi perbankan kepada seluruh masyarakat Indonesia sekaligus guna melayani kebutuhan seluruh nasabahnya maka Bank XYZ menargetkan pertumbuhan Agen Laku Pandai sebesar 50.000 Agen Laku Pandai dengan jumlah Transaksi sebesar 5 juta transaksi sampai dengan akhir tahun 2015 (website Bank XYZ). Pencapaian dapat didukung selama kinerja dari Agen Laku Pandai dilakukan sesuai standar yang ada dan dilakukan monitoring yang tepat dari seluruh pekerja Bank XYZ.

Peningkatan transaksi di Agen Laku Pandai merupakan fee based income bagi Bank XYZ, sehingga untuk mencapai target transaksinya Bank XYZ masih perlu memberikan pengetahuan kepada masyarakat dan nasabahnya untuk menggunakan Laku Pandai dalam memenuhi kebutuhan harian transaksi keuangannya. Maka berangkat dari semangat untuk meningkatkan kualitas jaringan dan layanan guna memenangkan persaingan dan memberlakukan keuangan inklusif, dalam rangka meningkatkan kepuasan nasabah Bank XYZ terutama para pengguna Laku Pandai, Bank XYZ harus mengoptimalkan Laku Pandai sebagai kepanjangan tangan dari BANK XYZ dalam menjangkau nasabah seluas-luasnya dan menghasilkan laba sebesar-besarnya. Jaringan BANK XYZ yang sangat luas di seluruh Indonesia merupakan competitive advantage yang tidak dimiliki oleh semua bank, dan hal ini wajib dioptimalkan sebagai strategi untuk memimpin pasar dalam dan luar negeri dimasa yang akan datang. Laku Pandai diyakini dapat menjadi jawaban dari tantangan-tantangan yang dihadapi oleh bank-bank untuk meningkatkan cost reduction, consumer loyalty dan mengedepankan prinsip safe and easy guna memenangkan persaingan di era Masyarakat Ekonomi ASEAN.

Kegiatan transaksi perbankan Laku Pandai yang safe and easy dinilai sangat cocok untuk melayani konsumen yang merupakan nasabah maupun nonnasabah BANK XYZ di level mikro, kecil dan menengah yang juga merupakan sektor pasar yang dikuasai BANK XYZ. Persebaran masyarakat mikro yang merata diseluruh Indonesia baik di daerah urban, sub-urban dan rural merupakan kesempatan untuk terus mengembangkan potensi Laku Pandai namun juga merupakan tantangan disaat yang bersamaan. Karakter dan lingkungan yang berbeda dari masyarakat mikro merupakan pertimbangan atas perlunya diferensiasi dalam target dan metode pemasaran Agen Laku Pandai guna memenangkan persaingan dan meningkatkan fee based income dari Agen Laku Pandai tersebut. Adapun strategi-strategi yang akan diterapkan pada Agen Laku Pandai harusnya berorientasi jangka panjang, berkesinambungan namun double karena kegiatankegiatan tersebut akan dilakukan oleh Agen Laku Pandai yang notabenenya bukan pekerja BANK XYZ dan tidak menjalani proses pendidikan secara intensif dari BANK XYZ. 
Kotler et al. (2010) menyatakan bahwa perusahaan harus dapat mengidentifikasi kegelisahan dan keinginan konsumen agar mampu membidik pikiran, hati dan spirit konsumen. Dikatakan juga bahwa didalam bisnis, mencintai konsumen berarti meraih loyalitas mereka, dengan cara memberikan nilai yang tinggi dan menyentuh perasaan dan jiwa mereka. Salah satu cara dalam memberikan nilai yang tinggi bagi konsumen adalah perusahaan dapat memberikan kepuasan bagi konsumennya.

Zeithaml et al. (2009), menyebutkan bahwa "service quality provokes customer satisfaction, loyalty, and behavioral intention". Dengan demikian dapat dikatakan bahwa kualitas pelayanan yang diberikan oleh Agen Laku Pandai dapat menjadi suatu kesatuan, sekaligus membentuk suatu pengalaman bagi konsumen yang dapat menentukan sikap dan juga intensi atau niat konsumen dalam bertransaksi di Laku Pandai.

Selain itu, Darmayana (2005) mengemukakan bahwa salah satu bentuk strategi pemasaran yang mampu mendukung dalam memasarkan produk, untuk menciptakan kepuasan konsumen adalah penggunaan bauran pemasaran. Menurut Tjiptono (2008) menyatakan bahwa kepuasan konsumen merupakan hal yang sangat penting kaitannya dengan pengembangan usaha. Pelanggan yang mempunyai loyalitas yang tinggi akan senantiasa menggunakan produk atau jasa yang disediakan perusahaan, dan tidak akan terpengaruh jasa yang ditawarkan pihak lain.

Beberapa permasalahan saat ini yang menimbulkan potensi kurangnya kepuasan pelanggan Agen Laku Pandai adalah permasalahan pihak ketiga sebagai orang yang mewakili Bank XYZ yaitu Agen Laku Pandai. Sebagian agen masih belum memahami produk BANK XYZ Link secara detail sehingga menimbulkan potensi gap antara kepentingan dan kepuasan pelanggan dari dimensi tangible dan reliability bagi konsumen Agen Laku Pandai. Agen Laku Pandai juga belum memahami teknologi yang dipakai di BANK XYZ Link. Hal ini berpotensi menimbulkan gap antara kepentingan dan kepuasan pelanggan konsumen dari dimensi assurance. Kurangnya perhatian agen pada standar pelayanan yang diberikan kepada konsumen Agen Laku Pandai dapat berpotensi gap antara kepentingan dan kepuasan pelanggan dari dimensi responsiveness dan emphaty. Dilihat dari lokasi tempat agen, terdapat beberapa permasalahan yaitu lokasi yang dekat dengan unit kerja Bank XYZ dan juga lokasi agen yang tidak berada di tempat keramaian atau tempat usaha. Hal ini tentunya akan cukup membuat kesulitan konsumen Agen Laku Pandai untuk mendatangi Agen Laku Pandai jika ingin melakukan transaksi sehingga lokasi yang demikian ini berbeda dengan harapan manajemen BANK XYZ yang bermaksud mendekatkan Agen Laku Pandai kepada masyarakat sehingga memudahkan dalam bertransaksi. Selain itu kurangnya informasi kepada konsumen Agen Laku Pandai dan tidak terpasangnya sertifikat Agen Laku Pandai dapat juga dapat mengurangi kepercayaan masyarakat ketika melakukan trasaksi di Agen Laku Pandai.

Berdasarkan permasalahan yang ada maka penelitian ini bertujuan untuk menganalisis tingkat kepentingan dan kepuasan pelanggan dari masing-masing faktor bauran pemasaran Laku Pandai. Selanjutnya, melakukan menganalisis faktor bauran pemasaran yang secara signifikan dapat memengaruhi kepuasan pelanggan Laku Pandai. Di samping itu, memformulasikan langkah-langkah pemasaran yang dapat diterapkan oleh BANK XYZLink untuk dapat memenangkan persaingan usaha.

\section{METODE PENELITIAN}

Penulis menentukan wilayah penelitian di kota Bandung, karena kota ini merupakan salah satu kota industri mikro yang sangat berkembang selain Yogyakarta dan Jakarta, begitu banyak Bank yang ingin memperebutkannya. Hal ini menunjukkan bahwa peluang pengembangan kemampuan Agen dan peningkatan transaksi Agen Laku Pandai di wilayah Bandung masih harus dilakukan.

Penelitian ini menggunakan penelitian deskriptif dan penelitian causal-explanatory. Penelitian deskriptif dilakukan untuk mendapatkan gambaran atau deskripsi karakteristik populasi dari data yang didapatkan, sedangkan penelitian causal-explanatory untuk melihat hubungan variabel yang satu memengaruhi variabel lainnya (Copper dan Schindler, 2014). Metode yang digunakan pada penelitian ini adalah metode kuantitatif untuk melakukan analisis data primer dan pengujian hipotesis penelitian dengan menggunakan analisis statistika.

Teknik pengambilan sampling dalam penelitian ini dilakukan dengan metode pengambilan sampel nonacak (non-probability sampling) dengan turunan 
Accidental Sampling, pengambilan sampel didasarkan pada kenyataan bahwa mereka kebetulan muncul. Pengambilan sampel kebetulan yang digunakan oleh peneliti adalah pengambilan sampel dipermudah dengan mempertimbangkan waktu, tenaga dan biaya yang dimiliki oleh peneliti dalam penelitian ini.

Penelitian ini akan dilakukan pada Agen Laku Pandai di wilayah Kota Bandung pada Bulan Desember 2015Maret 2016. Responden merupakan nasabah Agen Laku Pandai yang melakukan transaksi di Agen Laku Pandai minimal 3 bulan terakhir, dengan jumlah responden sebanyak 200 orang nasabah Agen Laku Pandai.

Pada proses pengumpulan data yang kita perlukan, akan diperoleh data yang selanjutnya dapat dibagi menjadi dua, yaitu data primer diperoleh langsung melalui teknik wawancara atau kuisioner. Kuisioner merupakan teknik pengumpulan data yang dilakukan dengan cara memberikan seperangkat pertanyaan atau pernyataan tertulis kepada responden untuk dijawab. Data primer dari penelitian ini diperoleh dari pembagian kuesioner yang akan diberikan setelah pengolahan data sekunder. Selanjutnya, data sekunder yang diperoleh dari penelusuran kepustakaan, baik melalui media cetak maupun media internet untuk mendapatkan berbagai informasi berupa buku, artikel, jurnal dan sumber lainnya yang relevan bagi penelitian ini. Data sekunder yang diperoleh dari penelitian ini berasal dari peraturan Bank Indonesia, Peraturan dari Otoritas Jasa Keuangan dan Peraturan dari BANK XYZ terkait Laku Pandai.

Teknik pengolahan data dan analisis yang digunakan pada penelitian ini adalah Analisis deskriptif (mendeskripsikan data secara statistik agar dapat memberikan informasi yang disajikan dalam bentuk grafik, tabel, nilai pemusatan dan nilai penyebaran); Analisis Korelasi Pearson (Korelasi Pearson atau yang disebut dengan korelasi sederhana merupakan suatu teknik statistik yang dipergunakan untuk mengukur kekuatan hubungan 2 Variabel dan juga untuk dapat mengetahui bentuk hubungan antara 2 Variabel tersebut dengan hasil yang sifatnya kuantitatif).

Penelitian ini juga menggunakan Importance Performance Analysis (IPA). Formula IPA pertama kali di formulasikan oleh Martilla tahun 1977 ini, menurut Huan dan Beaman (2005), digunakan sebagai alat analisis untuk mengetahui kebutuhan dan keinginan konsumen dan digunakan juga sebagai bahan yang baik bagi manajemen untuk memutuskan sesuatu yang dibutuhkan agar kebutuhan dan keinginan pelanggan dapatterpenuhi.Pada teknik ini responden diminta untuk menilai tingkat kepentingan dan kinerja perusahaan, kemudian nilai kepentingan dan kinerja tersebut di rata-rata dan dianalisis pada Importance Performance Matrix, dimana sumbu X mewakili persepsi kinerja, dan sumbu Y mewakili persepsi kepentingan.

Berkaitan dengan itu, peneliti juga mengunakan analisis Structural Equation Modelling (SEM). Suatu masalah yang paling mendasar dan sering dihadapi oleh peneliti adalah merumuskan pola keterkaitan atau kausalitas dari banyak variabel yang terkait. Melalui pemodelan yang berlandaskan teori tertentu upaya perumusan pola kausalitas umumnya menjadi lebih mudah, karena aspek validitas modelnya dapat dipertanggungjawabkan. Pendekatan masalah melalui SEM akan memberikan gambaran yang lebih komprehensif dalam mempelajari fenomena ilmiah. Salah satu kelebihan SEM adalah dapat mengukur suatu hubungan yang tidak bisa diukur secara langsung (Ghozali, 2001). Model yang digunakan dalam penelitian ini dibangun untuk mengukur hubungan kausalitas antara peubah laten yang memengaruhi pengambilan keputusan yang dilakukan oleh konsumen untuk menggunakan produk perbankan, berdasarkan teori dan penelitian terdahulu.

Keberhasilan suatu perusahaan tergantung dari cara bagaimana perusahaan tersebut memasarkan produk atau jasanya. Menurut Kotler (2000), di perusahaan terdapat keadaan yang dapat kendalikan dan yang tidak dapat dikendalikan. Keadaan yang dapat dikendalikan adalah hal-hal yang berhubungan dengan keadaan usaha itu sendiri seperti bauran pemasaran (marketing mix), sedangkan yang tidak dapat dikendalikan perusahaan antara lain, peraturan pemerintah, hukum yang berlaku, dan lain-lain. Dalam menyusun strategi pemasaran yang tepat perlu diketahui pula bagaimanakah segmen nasabah Laku Pandai, sehingga strategi yang akan di terapkan disesuaikan dengan segmen nasabah Laku Pandai. Berdasarkan kajian penelitian terdahulu serta teori yang mendukung untuk keputusan pembelian konsumen, maka dalam penelitian ini digunakan variabel-variabel yang dapat memengaruhi keputusan pembelian barang dan jasa, dalam bauran pemasaran jasa yaitu produk, lokasi, proses, pelayanan orang, dan bukti fisik.

Menurut Zeithaml, Berry, dan Parasuraman dalam Lovelock (2011)mendeskripsikan lima dimensi kualitas layanan yang dikenal dengan SERQUAL (service 
quality) terdiri dari Wujud fisik (Tangibles), yaitu kemampuan suatu perusahaan dalam menunjukkan eksistensinya kepada pihak eksternal. Penampilan sarana dan prasarana fisik perusahaan yang dapat diandalkan serta keadaan lingkungan sekitarnya merupakan salah satu cara perusahaan jasa dalam menyajikan kualitas layanan terhadap pelanggan. Diantaranya meliputi fasilitas fisik (gedung, buku, rak buku, meja dan kursi, dan sebagainya), teknologi (peralatan dan perlengkapan yang dipergunakan), serta penampilan pegawai; Keandalan (Reliability) adalah kemampuan perusahaan memberikan pelayanan sesuai dengan apa yang dijanjikan secara akurat dan terpercaya. Kinerja harus sesuai dengan harapan pelanggan yang tercermin dari ketepatan waktu, pelayanan yang sama untuk semua pelanggan tanpa kesalahan, sikap simpatik dan akurasi yang tinggi. Selanjutnya, daya tanggap (Responsiveness) adalah kemauan untuk membantu pelanggan dan memberikan jasa dengan cepat dan tepat dengan penyampaian informasi yang jelas. Mengabaikan dan membiarkan pelanggan menunggu tanpa alasan yang jelas menyebabkan persepsi yang negative dalam kualitas pelayanan. Selanjutnya, jaminan (Assurance) adalah pengetahuan, kesopan santunan dan kemampuan para pegawai perusahaan untuk menumbuhkan rasa percaya para pelanggan kepada perusahaan. Terakhir, empati (Empathy), yaitu memberikan perhatian yang tulus dan bersifat individual atau pribadi yang diberikan kepada pelanggan dengan berupaya memahami keinginan konsumen dimana suatu perusahaan diharapkan memiliki suatu pengertian dan pengetahuan tentang pelanggan, memahami kebutuhan pelanggan secara spesifik, serta memiliki waktu pengoperasian yang nyaman bagi pelanggan.

Memperhatikan hal tersebut, maka variabel-variabel bauran pemasaran ini akan di kelompokkan berdasarkan dimensi kualitas pelayanan yaitu tangible, reliability, assurance, responsiveness dan empathy. Dari dimensidimensi ini kemudian akan diukur gap antara tingkat kepentingan layanan dan kepuasan (kinerja) layanan, sehingga akan didapatkan gambaran prioritas variable yang perlu perbaikan layanan. Selain itu dilakukan pula pengukuran tingkat kepuasan pelanggan serta kontribusi masing-masing dimensi kepuasan tersebut terhadap kepuasan pelanggan Laku Pandai. Hasil dari pengukuran-pengukuran ini kemudian dianalisis dan akan menjadi bahan masukan bagi strategi pemasaran produk Laku Pandai selanjutnya.
Berdasarkan permasalahan maka di tentukan hipotesis penelitian sebagai berikut:

H1 : Dimensi kualitas pelayanan tangible berpengaruh positif terhadap kepuasan pelanggan

H2 : Dimensi kualitas pelayanan reliability berpengaruh positif terhadap kepuasan pelanggan

H3 : Dimensi kualitas pelayanan assurance berpengaruh positif terhadap kepuasan pelanggan

H4 : Dimensi kualitas pelayanan responsiveness berpengaruh positif terhadap kepuasan pelanggan

H5 : Dimensi kualitas pelayanan empathy berpengaruh positif terhadap kepuasan pelanggan

\section{HASIL}

Tingkat Kepentingan dan Kepuasan Pelanggan dari Masing-masing Faktor Bauran Pemasaran Laku Pandai

\section{Analisis Korelasi Pearson}

Korelasi antara Usia dan Kepuasan Keseluruhan memiliki arah negatif sebesar 0,122 yang berarti korelasi antar kedunya sangat rendah. Dari keterangan diatas dapat disampaikan bahwa semakin tinggi usia seseorang memiliki kecenderungan untuk meminta pelayanan yang lebih dari sekedar di Agen Laku Pandai. korelasi antar Pendidikan dan Kepuasan Keseluruhan memiliki arah positif sebesar 0,075 yang berarti korelasi antar kedua sangat rendah. Dari keterangan diatas dapat disampaikan bahwa semakin tinggi pendidikan seseorang memiliki kecenderungan untuk meminta pelayanan lebih dengan standar perbankan, sedangkan ybs akan memperoleh hal tersebut di unit kerja Bank XYZ. Korelasi antara Pengeluaran dan Kepuasan Keseluruhan memiliki arah positif sebesar 0,323 hal ini berarti korelasi antar kedua variabel rendah. Dari penjelasan tersebut diatas, dapat disampaikan bahwa semakin tinggi pengeluaran seseorang memiliki kecenderungan untuk beralih bertransaksi dari Agen Laku Pandai. Hasil Korelasi Pearson selengkapnya pada Tabel 1. 
Tabel 1. Korelasi Pearson

\begin{tabular}{lcccc}
\hline \multicolumn{1}{c}{ Variabel } & & Pengeluaran & Usia & Pendidikan \\
\hline \multirow{2}{*}{ Tangible } & Pearson Correlation &, $177^{*}$ &, 006 &,- 133 \\
& Sig. (2-tailed) &, 012 &, 936 &, 061 \\
Reliability & Pearson Correlation & $.360^{* *}$ &,- 021 & $-.181^{*}$ \\
& Sig. (2-tailed) &, 000 &, 767 &, 010 \\
Assurance & Pearson Correlation &, $333^{* *}$ &, 060 & $-.200^{* *}$ \\
& Sig. (2-tailed) &, 000 &, 400 &, 004 \\
Responsiveness & Pearson Correlation &, $260^{* *}$ &, 047 &,- 119 \\
& Sig. (2-tailed) &, 000 &, 510 &, 094 \\
Empathy & Pearson Correlation &, $336^{* *}$ &,- 014 &,- 090 \\
& Sig. (2-tailed) &, 000 &, 841 &, 206 \\
Kepuasan & Pearson Correlation &, $323^{* *}$ &,- 122 &, 075 \\
Keseluruhan & Sig. (2-tailed) &, 000 &, 086 &, 290 \\
\hline
\end{tabular}

Dalam memetakan antara tingkat kepentingan atribut dengan tingkat kinerja atau pelaksanaannya maka digunakan analisis IPA. Hasil analisis IPA dapat dilihat pada Gambar 2. Kuadran I pada Gambar 2, menunjukkan atribut yang memiliki kepentingan tinggi akan tetapi dalam pelaksanaannya pihak manajemen organisasi belum melakukannya secara maksimal, sehingga organisasi harus memperbaiki dan meningkatkan kinerjanya. Variabel yang berada pada kuadran I adalah Agen Laku Pandai cepat tanggap terhadap complain dan kemudahan menemui Agen Laku Pandai jika ada permasalahan transaksi. Hal ini diharapkan dapat menjadi perhatian manajemen Bank XYZ dengan lebih seringnya dilakukan pelatihan tentang produk dan complain handling Laku Pandai.

Kuadran II pada Gambar 2, menunjukkan atribut yang memiliki kepuasan dan kepentingan tinggi, serta menunjukkan organisasi telah berhasil melaksanakan dengan baik, sehingga perlu dipertahankan. Pada evaluasi kinerja Agen Laku Pandai, terdapat beberapa variabel yang berada pada kuadran II yaitu a) Alat atau teknologi yang digunakan Laku Pandai berkualitas, hal ini didukung oleh aplikasi sistem yang di tanamkan memang yang aplicable dengan sistem mesin EDC itu sendiri hal ini telah memberikan kepuasan yang sangat tinggi bagi nasabah; $b$ ) Transaksi yang dilakukan di Agen Laku Pandai selalu berhasil dan Transaksi dapat dilakukan dengan cepat,hal ini didukung oleh penggunaan jaringan operator yang mendukung disuatu wilayah tersebut dan dikarenakan sistem server yang sangat mendukung maka penggunaan jaringan khusus Laku Pandai memang masih menjadi prioritas Bank XYZ, dengan masuknya pada kuadran satu maka dapat dikatakan kepuasan nasabah dapat terpenuhi; c)
Bertransaksi di Laku Pandai mudah dilakukan karena produk - produk e-channel yang ditawarkan merupakan produk yang memang dibutuhkan oleh nasabah untuk kegiatan sehari-hari; d) Agen Laku Pandai memiliki reputasi yang bagus,hal ini didukung oleh pemilihan Agen Laku Pandai secara selektif dan sangat memperhatikan reputasi Agen Laku Pandai, dengan melihat simpanan dan transaksi keuangan Agen Laku Pandai selama menjadi debitur ataupun nasabah Bank XYZ; e) Aman ketika melakukan transaksi di Agen Laku Pandai merupakan salah satu hal yang menjadi perhatian Bank XYZ dan nasabahpun menyatakan demikian dikarenakan pada setiap transaksi yang dilakukan oleh nasabah seluruhnya tercatat pada sistem dan mendapatkan tanda bukti transaksi.

Kuadran III pada Gambar 2, menunjukkan atribut yang kurang penting dan kepuasannya rendah. Dalam pelaksanaannya manajemen tidak terlalu memprioritaskan perbaikan, yaitu variabel sumber informasi, baik poster maupun brosur, jam operasional, Agen Laku Pandai selalu menjawab semua pertanyaan yang diajukan konsumen serta Agen Laku Pandai dapat dihubungi kapan saja ketika terdapat kebutuhan transaksi. Lokasi Agen Laku Pandai sangat memungkinkan nasabah untuk bertanya dari pada membaca Brosur yang tersedia.

Kuadran IV pada Gambar 2, menunjukkan atribut yang kurang penting, akan tetapi pelaksanaannya sangat memuaskan, sehingga organisasi perlu mengurangi hasil yang dicapai agar dapat mengefisienkan sumberdaya organisasi. Variabel yang berada pada kategori ini adalah variabel lokasi, kenyamanan tempat menunggu, serta kenyamanan ketika bertransaksi di Laku Pandai. 
Selanjutnya Bank XYZ akan mengkondisikan agar pada Agen Laku Pandai dapat memperhatikan tempat usaha yang dimiliki.

\section{Faktor Bauran Pemasaran yang Memengaruhi Kepuasan Pelanggan Laku Pandai}

Berdasarkan Structural Equation Modelling (SEM) (Gambar 3), Hasil penelitian dengan menggunakan SEM menunjukkan hasil bahwa kepuasan nasabah dipengaruhi oleh variabel tangible, realibility, assurance, responsibility, dan empathy, sedangkan loyalitas nasabah sangat dipengaruhi oleh kepuasannya. Jika dilihat dari besarnya pengaruh antar variabel, maka variabel emphaty paling menentukan kepuasan nasabah terhadap Laku Pandai. Variabel responsibility merupakan faktor kedua yang memberikan pengaruh besar dalam menentukan kepuasan nasabah, kemudian diikuti oleh tangible, realibility dan assurance.

Jika nasabah merasa puas dengan pelayanan dan fasilitas yang disediakan oleh Agen Laku Pandai, maka nasabah akan memiliki loyalitas terhadap Agen Laku Pandai. Dari model yang dibangun, pengaruh langsung kepuasan nasabah terhadap loyalitasnya adalah sebesar 0,94 berarti bahwa nasabah Agen Laku Pandai memiliki loyalitas untuk tetap bertransaksi di Agen Laku Pandai.

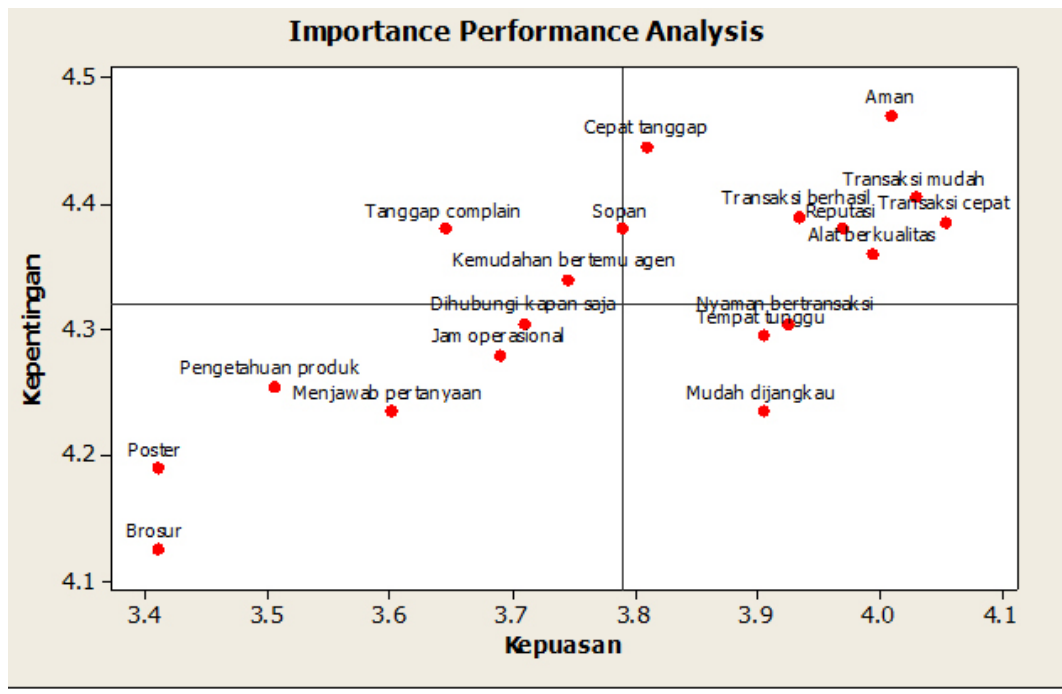

Gambar 2. Hasil Importance Performance Analysis (IPA)

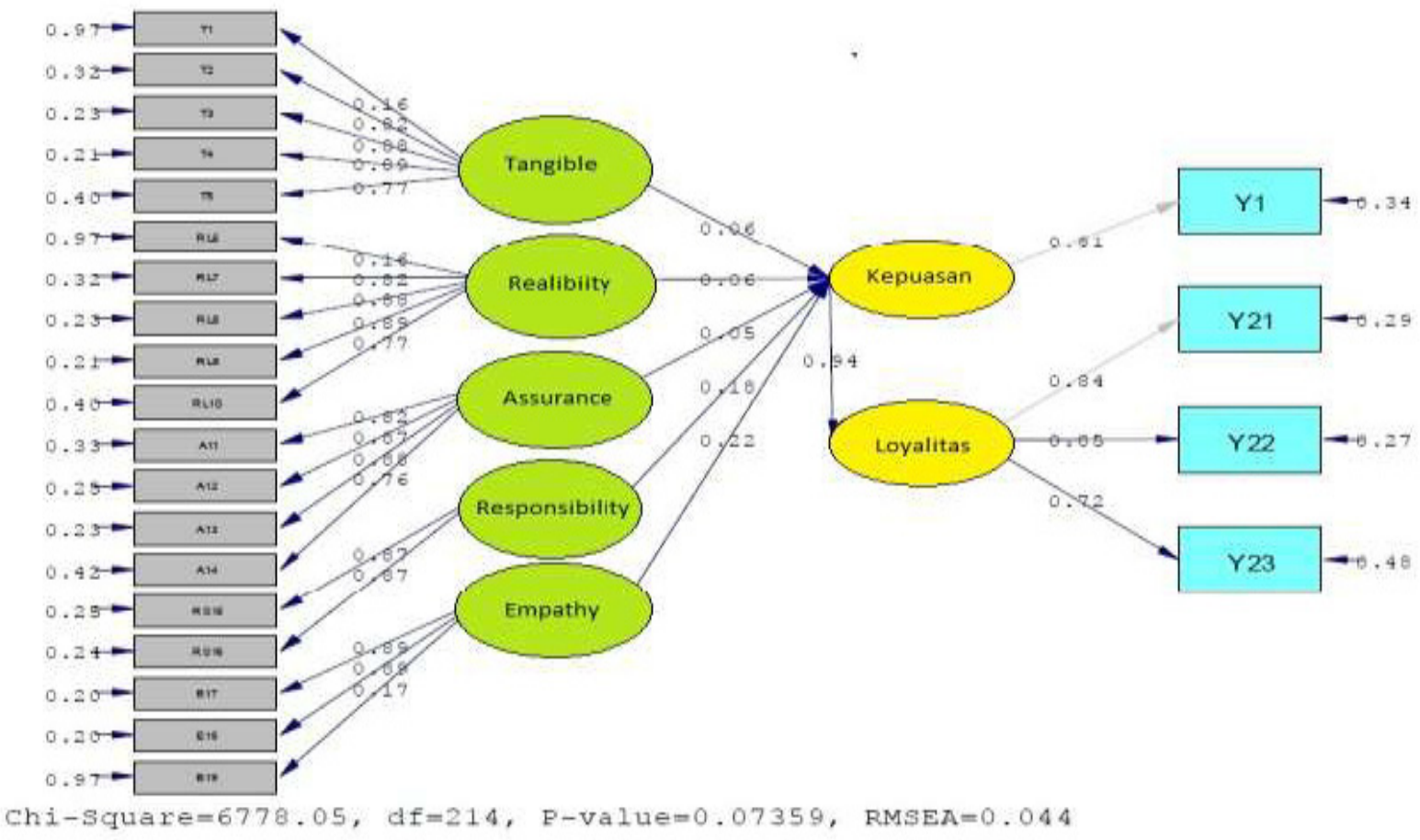

Gambar 3. Model struktural analisis kepuasan 


\section{Formulasikan Langkah-langkah Pemasaran}

Dalam rangka mempertahankan dan meningkatkan kinerja Agen Laku Pandai, beberapa hal yang harus dipertahankan oleh manajemen Bank XYZ adalah penggunaan jaringan mesin EDC Agen Laku Pandai dengan adanya jaringan yang baik maka makin cepat dan terpenuhinya layanan perbankan dari nasabah Agen Laku Pandai. Mekanisme pemilihan kerja sama dengan Agen Laku Pandai, hal ini merupakan awal dari suau proses karena perekrutan yang tepat dengan melihat track record dari calon Agen Laku Pandai merupakan suatu mekanisme penentuan pencapaian kinerja Agen Laku Pandai kedepannya.

Mekanisme pemilihan lokasi Agen Laku Pandai yang berada dekat atau ditengah dengan perumahan/ desa merupakan hal yang sangat tepat dilakukan oleh Bank XYZ dimana hal ini semakin mendekatkan layanan perbankan Bank XYZ melalui mekanisme keagenan kepada masyarakat sehingga kedepan dalam menetapkan pemilihan para calon Agen Laku Pandai agar Bank XYZ memperhatikan pekerjaan dari penduduk sekitar, jarak tempuh ke perbankan terdekat, calon Agen Laku Pandai yang memiliki reputasi yang baik dilingkungannya. Penentuan standar layout dari Agen Laku Pandai dan penentuan standar layanan dari para Agen Laku Pandai, hal ini merupakan peningkatan layanan dan kenyamanan Agen Laku Pandai kepada nasabahnya. Hal-hal ini sangat memberikan kepuasan bagi nasabah, karena dengan mempertahankan atau bisa dilakukan peningkatan maka kepuasan pelanggan akan lebih mudah dan cepat tercapai. Tetapi harap manajemen tetap memperhatikan kebutuhan nasabah.

\section{Implikasi Manajerial}

Beberapa hal yang masih harus menjadi perhatian manajemen Bank XYZ guna meningkatkan kepuasan dan loyalitas nasabahnya seperti penggunaan media pemasaran produk-produk di Agen Laku Pandai, terdapat calon nasabah yang senang bertanya tentang experience menggunakan produk-produk di Agen Laku Pandai baik itu kepada nasabah lainnya atau ke Agen Laku Pandai, tetapi terdapat juga calon nasabah yang sangat nyaman bila membaca tentang fitur yang dapat dilayani oleh Agen Laku Pandai melalui media brosur atau poster sehingga diharapkan manajemen dapat membuat tampilan yang menarik dan penjelasan yang detail tentang Laku Pandai sehingga masyarakat akan lebih tertarik dan selanjutkan akan menggunakannya.
Guna meningkatkan nilai dan jumlah transaksi nasabah di Agen Laku Pandai maka dapat dilakukan lomba bagi Agen Laku Pandai yang dimulai dari tingkat wilayah dan dilanjutkan dengan tingkat nasional sehingga akan sangat memotivasi para Agen Laku Pandai untuk mengejar transaksinya. Selain itu, Bank XYZ dapat melakukan pengembangan teknologi transaksi Agen Laku Pandai berbasis web dan aplikasi mobile sehingga jumlah Agen Laku Pandai dapat bertambah dan memberikan akses baru bagi Agen Laku Pandai eksisting. Teknik dalam rekrutment para Agen Laku Pandai merupakan suatu langkah luar biasa, karena dengan melakukan selektif Agen Laku Pandai baik yang sudah menjadi agen maupun yang akan menjadi agen akan memastikan bahwa tahap pertama untuk mencapai target telah tercapai.

\section{KESIMPULAN DAN SARAN}

\section{Kesimpulan}

Berdasarkan hasil penelitian yang telah dilakukan, disimpulkan bahwa dari faktor-faktor yang diteliti, terdapat beberapa faktor yang memiliki tingkat kepentingan dan kepuasan pelanggan, yaitu alat atau teknologi yang digunakan Laku Pandai berkualitas, transaksi yang dilakukan di Agen Laku Pandai selalu berhasil, transaksi dapat dilakukan dengan cepat, bertransaksi di Laku Pandai mudah dilakukan, Agen Laku Pandai memiliki reputasi yang bagus, aman ketika melakukan transaksi di Agen Laku Pandai, Agen Laku Pandai menguasai pengetahuan tentang segala produk Laku Pandai, Agen Laku Pandai selalu bersikap sopan selama berinteraksi dengan konsumen, ketika terjadi permasalahan dalam transaksi Agen Laku Pandai dapat dengan cepat menyelesaikannya.

Dari kelima variabel yang ada yaitu tangible, realibility, assurance, responsibility, dan empathy. Variabel emphaty merupakan variabel yang menentukan tingkat kepuasan nasabah terhadap pelayanan yang diberikan oleh Agen Laku Pandai. Variabel lainnya secara signifikan juga memengaruhi kepuasan nasabah Agen Laku Pandai. Berdasarkan tingkat kepuasan ini maka dapat dipastikan begitu banyak nasabah Agen Laku Pandai yang bersedia untuk tetap bertransaksi di Agen Laku Pandai walaupun banyak penawaran menarik dari Agen Laku Pandai lainnya, selain itu nasabah Agen Laku Pandai telah merekomendasikan Agen Laku Pandai kepada orang lain dan selalu bercerita 
tentang pengalaman bertransaksi di Agen Laku Pandai tempatnya bertransaksi.

Dalam menghadapi persaingan, Agen Laku Pandai melakukan langkah-langkah guna mendukung pelaksanaan pemasarannya seperti: Agen Laku Pandai melakukan penjelasan tentang produk-produk yang dapat dilakukan di arisan didekat rumahnya. Agen Laku Pandai melakukan promosi kepada setiap orang yang belanja di tempat tokonya berada. Agen Laku Pandai mengambil kesempatan dengan mendatangi rumahrumah penduduk sehingga nasabahnya merasa terbantu tanpa harus mereka yang berjalan ke lokasi.

\section{Saran}

Saran yang diberikan antara lain pentingnya pengembangan penggunaan sarana jaringan komunikasi dengan satelit dan aplikasi web merupakan prasarana harus segera dipenuhi manajemen. Selanjutnya, penyelenggaran pendidikan bagi para Agen Laku Pandai dengan menekankan tentang tata cara penanganan komplain dan produk-produk terbaru dari Laku Pandai. Di samping itu, perlu disiapkan media promosi yang memungkinkan bagi Agen Laku Pandai untuk mudah untuk memberikan kepada nasabahnya sehingga bisa dalam bentuk media yang mudah untuk dicetak atau dengan menggunakan media email (softcopy).

Saran bagi peneliti selanjutnya, diharapkan dapat memfokuskan penelitian pada jenis produk perbankan Bank BRI lainnya sehingga dapat mengukur tingkat kepuasan nasabah dan loyalitas nasabah terhadap produk dan layanan yang diberikan. Selanjutnya peneliti memberikan saran agar wilayah penelitian disesuaikan dengan memperhatikan tingkat kinerja dari masing-masing produk yang akan di teliti.

\section{DAFTAR PUSTAKA}

Cooper DR, Schindler PS. 2014. Business Research Methods. Twelfth Edition. New York: McGrawHill International.

Darmayana W. 2005. Analisis faktor-faktor bauran pemasaran yang memengaruhi kepuasan konsumen pembeli rumah tipe menengah ke atas di Kecamatan Ngaglik, Kabupaten Sleman, Yogyakarta. Jurnal Manajemen Dan Kewirausahaan 3(2): 65-73.

Ghozali I. 2001. Aplikasi Analisis Multivariate Dengan Program SPSS. Semarang: Badan Penerbit Universitas Diponegoro.

Huan T, Beaman J. 2005. Importance Performance Analysis : The Need To Bank XYZdge Solitudes For Its Effective Use. Canadian Association For Leisure Studies

Kotler P. 2000. Manajemen Pemasaran. Jakarta: PT. Prenhallindo. https://doi. org/10.1002/9781118257883.

Lovelock C,Wirt J. 2011. Services Marketing. People, Techonology, Strategy. Pearson. 7th Ed. Jilid ke-1. Amerika: Boston Pearson.

Kotler P, Kartajaya H, Setiawan I, 2010. Marketing 3.0. Jakarta:Erlangga.

Tjiptono F. 2008. Strategi Pemasaran. Edisi Kedua, Malang: Penerbit Bayu Media Malang.

Zeithaml VA, Bitner MJ, Gremler DD. 2009. Service Marketing Integrating Customer FoculAcross the Firm. New York. McGraw-Hill International. 